\title{
L-Threonine Production by a Mutant of Arthrobacter paraffineus ${ }^{\dagger}$
}

\author{
Hiroshi Kase and Kiyoshi Nakayama \\ Tokyo Research Laboratory, Kyowa Hakko Kogyo Co., Ltd., \\ Machida-shi, Tokyo
}

Received December 19, 1972

\begin{abstract}
An isoleucine leaky auxotroph of Arthrobacter paraffineus, which was isolated by Takayama et al. ${ }^{3}$ as a mutant producing $\mathrm{L}$-threonine and $\mathrm{L}$-valine from $n$-paraffin, was subjected to further mutagenesis in an attempt to obtain better L-threonine producers. Some of the double auxotrophs derived from the isoleucine auxotroph and some of their revertants with respect to isoleucine requirement produced more $\mathrm{L}$-threonine than the original isoleucine auxotroph. In contrast to the original isoleucine auxotroph, a revertant derived from a methionine plus isoleucine double auxotroph, KY7135, produced an increased amount of L-threonine and a decreased amount of L-valine. The optimum level of L-methionine for L-threonine production in KY7135 was much higher $(1000 \sim 2000 \mu \mathrm{g} / \mathrm{ml})$ with $n$-paraffin medium than with sorbitol or mannitol medium $(10 \sim 50 \mu \mathrm{g} / \mathrm{ml})$. L-Threonine production reached a maximum level $(11.5 \mathrm{mg} / \mathrm{ml})$ in 7 days incubation with the medium containing $10 \% n$-paraffin $\left(\mathrm{C}_{12} \sim \mathrm{C}_{14}\right.$ rich). Several mutants which produce L-threonine more than $12 \mathrm{mg} / \mathrm{ml}$ were obtained from KY 7135 by monocolony isolation procedure.
\end{abstract}

L-Threonine production from hydrocarbon has recently been reported by Takayama et $a I^{3)}$ in our laboratory. They found that an isoleucine leaky auxotroph, KY7104, derived from Arthrobacter paraffineus, a hydrocarbon utilizer, produced a large amount of both L-threonine and L-valine from $n$-paraffin at the same time. In a favorable condition, the maximum amount of L-threonine and L-valine production was about $9 \mathrm{mg} / \mathrm{ml}$ each.

In the course of the studies on L-threonine fermentation using microbial mutants, KY7104 was subjected to futher mutagenesis in an attempt to obtain better L-threonine producers from hydrocarbon. Thus, many double auxotrophs and their revertants with respect to isoleucine requirement were derived and screened for their ability to produce an increased amount of L-threonine. In the present paper, the results obtained with one of the revertants which produced more Lthreonine but much less L-valine than the original strain are described.

$\dagger$ Studies on L-Threonine Fermentation Part III, see Reference 1, 2).

\section{MATERIALS AND METHODS}

Microorganisms. Arthrobacter paraffineus KY7104 (Ile $-/ a \mathrm{AB}^{-} / a \mathrm{~KB}^{-} / \mathrm{Thr}^{-} / \mathrm{Hom}^{-}$) isolated by Takayama et al. ${ }^{31}$ was employed as a starting strain.

Culture medium. Minimal and complete medium of the following compositions were used for mutational experiments. Minimal medium; $10 \mathrm{~g}$ fructose, $1 \mathrm{~g}$ $\mathrm{NH}_{4} \mathrm{H}_{2} \mathrm{PO}_{4}, 0.2 \mathrm{~g} \mathrm{KCl}, 0.2 \mathrm{~g} \mathrm{MgSO}_{4} \cdot 7 \mathrm{H}_{2} \mathrm{O}, 5 \mathrm{mg}$ thiamine and $1 \mathrm{ml}$ of trace element solution in a liter of distilled water ( $\mathrm{pH} \mathrm{7.2).} \mathrm{Composition} \mathrm{of} \mathrm{the} \mathrm{trace}$ element solution has been previously described.2 Complete medium; $10 \mathrm{~g}$ peptone, $10 \mathrm{~g}$ meat extract, $5 \mathrm{~g}$ yeast extract and $3 \mathrm{~g} \mathrm{NaCl}$ in a liter of water $(\mathrm{pH}$ 7.2). Seed medium contained $5 \%$ sorbitol, $1 \%$ meat extract, $1 \%$ peptone, $0.5 \%$ yeast extract and $0.3 \%$ $\mathrm{NaCl}$ ( $\mathrm{pH}$ 7.4). The composition of the fermentation medium is described in the legend of each Table and Figure.

Mutation. Mutations were induced by treatment of the bacterial cells with ultraviolet light or $\mathrm{N}$ methyl- $\mathrm{N}^{\prime}$-nitro- $\mathrm{N}$-nitrosoguanidine (NTG), as previously described. ${ }^{1,21}$

For the selection of double auxotrophs, NTG treated cells were tested by replica method, and those which grew well on the minimal medium supplemented with L-isoleucine, L-methionine, L-lysine and $a, \varepsilon-$ diaminopimelic acid, but hardly on the minimal medium supplemented with $\mathrm{L}$-isoleucine were selected.

Culture method. Thirty milliliters of a seed 
medium in a $250 \mathrm{ml}$ Erlenmeyer flask was inoculated with one loopful of an organism grown on a bouillon agar slant, and incubated on a rotary shaker operated at $220 \mathrm{rpm}$. After incubation for $24 \mathrm{hr}$ at $30^{\circ} \mathrm{C}, 1 \mathrm{ml}$ of the seed culture was transferred into a $250 \mathrm{ml}$ Erlenmeyer flask containing $10 \mathrm{ml}$ of a fermentation medium. The flask was incubated at $30^{\circ} \mathrm{C}$ on a rotary shaker for $4 \sim 10$ days.

Analysis, L-Threonine and L-valine were estimated by colorimetry with ninhydrin after paperchromatographical separation. The paperchromatography was performed on "Toyo Roshi No. 50" paper by use of the following solvent system; methylethylketone-nbutanol-conc. ammonia-water $(100: 100: 5: 60 \mathrm{v} / \mathrm{v})$ or $n$-butanol-acetic acid-water $(4: 1: 2 \mathrm{v} / \mathrm{v})$.

\section{RESULTS}

\section{Isolation of mutant}

Figure 1 shows the genealogy of Arthrobacter paraffineus KY7135 which was used to study on some cultural conditions for Lthreonine production. Some of the double auxotrophs including lysine or $a, \varepsilon$-diaminopimelic acid plus isoleucine and methionine plus isoleucine auxotrophs, and some of their revertants with respect to isoleucine requirement were found to produce more L-threonine than the original strain. For example, KY7135, a revertant derived from an isoleucine plus methionine auxotroph KY7137, produced more L-threonine than the original strain KY7104. In contrast to KY7104 or KY7137, the amount of L-valine produced by some revertants including KY7135 was much reduced.

2. Cultural conditions for L-threonine production with KY7135

a) Effect of carbon source and L-methionine concentration on L-threonine production. Sorbitol, mannitol and $n$-paraffin were compared with respect to L-threonine production at various levels of L-methionine (Table I). $n$-Paraffin gave much higher yield than sorbitol or mannitol. With mannitol or sorbitol, the optimal level of $\mathrm{L}$-methionine for L-threonine production was $10 \sim 50 \mu \mathrm{g} / \mathrm{ml}$, and higher levels of L-methionine (above

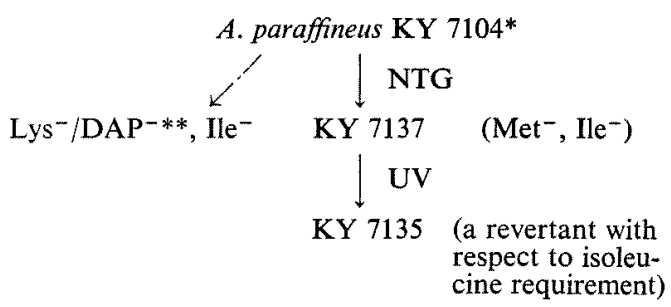

FIG. 1. Genealogy of Arthrobacter paraffineus KY 7135 .

* see Reference 3 )

**, , s-diaminopimelic acid

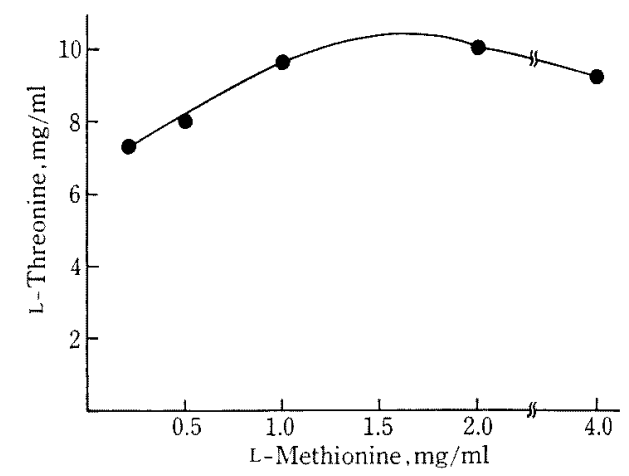

FIG. 2. Effect of L-Methionine on L-Threonine Production in A. paraffineus KY 7135.

Basal medium; $n$-paraffin $10 \%,\left(\mathrm{NH}_{4}\right)_{2} \mathrm{SO}_{4} 2 \%$, $\mathrm{KH}_{2} \mathrm{PO}_{4} 0.1 \%, \mathrm{~K}_{2} \mathrm{HPO}_{4} 0.1 \%, \mathrm{MgSO}_{4} \cdot 7 \mathrm{H}_{2} \mathrm{O} \quad 0.1 \%$, trace element solution $1 \mathrm{ml} / \mathrm{liter}$ thiamine $1 \mu \mathrm{g} / \mathrm{ml}$, $\mathrm{CaCO}_{3} 2 \%(\mathrm{pH} 7.4)$.

Incubation time; 8 days.

$100 \mu \mathrm{g} / \mathrm{ml}$ ) supressed the production of $\mathrm{L}$ threonine. In contrast, high level (above $200 \mu \mathrm{g} / \mathrm{ml}$ ) of L-methionine was favorable for L-threonine production in the case of $n$ paraffin. Figure 2 shows the effect of high level of L-methionine on L-threonine production in 8 days incubation with $n$-paraffin. As L-methionine level increased, L-threonine yield increased steadily to a maximum (at $1000 \sim 2000 \mu \mathrm{g} / \mathrm{ml}$ of $\mathrm{L}$-methionine) and then slowly decreased.

D-Isomer of methionine was proved to be as effective as L-isomer on L-threonine production (Table II).

b) Effect of incubation time on L-threonine production. As Fig. 3 shows, L-threonine concentration slowly increased and reached to a maximum level in about 8 days. Slight 
Table I. Effect of Carbon Source and l-Methionine on L-Threonine Production in A. paraffineus KY7135

Incubation time; $98 \mathrm{hr}$

Basal medium; $\left(\mathrm{NH}_{4}\right)_{2} \mathrm{SO}_{4} 2 \%, \mathrm{KH}_{2} \mathrm{PO}_{4} 0.1 \%, \mathrm{~K}_{2} \mathrm{HPO}_{4} 0.1 \%, \mathrm{MgSO}_{4} \cdot 7 \mathrm{H}_{2} \mathrm{O} 0.1 \%$, trace element solution $1 \mathrm{ml} /$ liter, thiamine $1 \mu \mathrm{g} / \mathrm{ml}, \mathrm{CaCO}_{3} 2 \%(\mathrm{pH} 7.4)$.

\begin{tabular}{|c|c|c|c|c|c|}
\hline $\begin{array}{l}\text { Carbon } \\
\text { source }\end{array}$ & $\%$ & $\begin{array}{l}\text { Concn. of } \\
\text { L-methionine } \\
\mu \mathrm{g} / \mathrm{ml}\end{array}$ & $\mathrm{pH}$ & $\begin{array}{c}\text { Growth } \\
\left(\mathrm{OD}^{*} 1 / 10\right)\end{array}$ & $\begin{array}{l}\text { L-Threonine } \\
\text { found } \mathrm{mg} / \mathrm{ml}\end{array}$ \\
\hline \multirow{5}{*}{ Mannitol } & \multirow{5}{*}{5} & 0 & 6.7 & 0.359 & $\mp$ \\
\hline & & 10 & 6.6 & 0.320 & $0.5( \pm)$ \\
\hline & & 50 & 6.6 & 0.428 & $\mp$ \\
\hline & & 100 & 6.4 & 0.458 & $\mp$ \\
\hline & & 200 & 6.5 & 0.459 & $\mp$ \\
\hline \multirow{5}{*}{ Sorbitol } & \multirow{5}{*}{5} & 0 & 5.9 & 0.745 & $0.6( \pm \sim+)$ \\
\hline & & 10 & 5.8 & 0.890 & $\pm \sim+$ \\
\hline & & 50 & 5.9 & 0.650 & $\pm \sim+$ \\
\hline & & 100 & 6.4 & 0.720 & \pm \\
\hline & & 200 & 6.8 & 0.725 & $\bar{F}$ \\
\hline \multirow{8}{*}{ n-Paraffin } & \multirow{4}{*}{5} & 50 & 5.7 & ++ & 3.8 \\
\hline & & 100 & 6.1 & ++ & 4.4 \\
\hline & & 200 & 6.0 & ++ & 5.0 \\
\hline & & 500 & 6.1 & ++ & 5.0 \\
\hline & \multirow{4}{*}{10} & 50 & 6.1 & $+t$ & 1.9 \\
\hline & & 100 & 6.2 & ++ & 2.7 \\
\hline & & 200 & 6.2 & ++ & 4.0 \\
\hline & & 500 & 6.0 & ++ & 3.4 \\
\hline
\end{tabular}

* Optical density at $660 \mathrm{~m} \mu$

TABle II. EFFECT OF Methionine IsOMERS ON L-Threonine Production in $A$. paraffineus KY7135

Incubation time; 7 days

Basal medium; $n$-paraffin $10 \%,\left(\mathrm{NH}_{4}\right)_{2} \mathrm{SO}_{4} 2 \%$, $\mathrm{KH}_{2} \mathrm{PO}_{4} 0.1 \%, \mathrm{~K}_{2} \mathrm{HPO}_{4} 0.1 \%, \mathrm{MgSO}_{4} \cdot 7 \mathrm{H}_{2} \mathrm{O} 0.1 \%$, trace element solution $1 \mathrm{ml} / \mathrm{liter}$, thiamine $2 \mu \mathrm{g} / \mathrm{ml}$, $\mathrm{CaCO}_{3} 2 \%$.

\begin{tabular}{lccc}
\hline Methionine isomers $^{a \mid}$ & pH & Growth & $\begin{array}{c}\text { L-Threonine } \\
\text { found } \mathrm{mg} / \mathrm{ml}\end{array}$ \\
\hline L-isomer & 6.8 & +++ & 7.5 \\
D-isomer & 6.7 & +++ & 7.6 \\
DL-isomer & 6.1 & +++ & 7.2 \\
${ }^{b}$ & 7.6 & \pm & 3.4 \\
\hline
\end{tabular}

a) The concentration of methionine isomers was each $2 \mathrm{mg} / \mathrm{ml}$.

b) Control, no methionine was added to the fermentation medium.

degradation of L-threonine was noted in 10 days incubation.

c) Effect of thiamine concentration on Lthreonine production. KY7135 requires thiamine for growth. Effect of thiamine

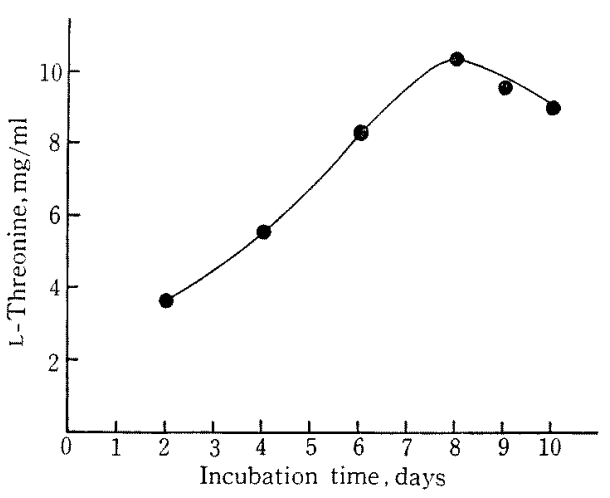

FIG. 3. Effect of Incubation Time on L-Threonine Production in $A$. paraffineus KY 7135.

The medium described in the footnote of Fig. 2 was supplemented with $2 \mathrm{mg} / \mathrm{ml}$ of DL-methionine.

concentration on L-threonine production was investigated. The result is presented in Fig. 4. Unexpectedly, L-threonine production was slightly affected by thiamine level. Even if thiamine was not added to the fermentation medium, the amount of $\mathrm{L}$-threonine production 


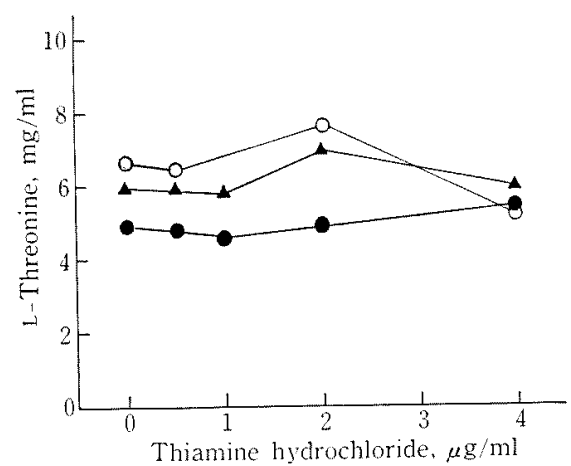

FIG. 4. Effect of Thiamine on L-Threonine Production in A. paraffineus KY 7135 .

Basal medium; n-paraffin $10 \%, \quad\left(\mathrm{NH}_{4}\right)_{2} \mathrm{SO}_{4} 2 \%$, $\mathrm{KH}_{2} \mathrm{PO}_{4} 0.1 \%, \mathrm{~K}_{2} \mathrm{HPO}_{4} 0.1 \%, \mathrm{MgSO}_{4} \cdot 7 \mathrm{H}_{2} \mathrm{O} 0.1 \%$, trace element solution $1 \mathrm{ml} / \mathrm{liter}, \mathrm{CaCO}_{3} 2 \%(\mathrm{pH} 7.4)$. Incubation time; 7 days.

DL-Methionine concentration; $-100 \mu \mathrm{g} / \mathrm{ml}$;

$\Delta-\boldsymbol{\Lambda}, 500 \mu \mathrm{g} / \mathrm{ml} ; \quad 0-0,2000 \mu \mathrm{g} / \mathrm{ml}$.

was comparable to that in high level of thiamine.

d) Effect of ammonium sulfate on L-threonine production. Effect of ammonium sulfate concentration on L-threonine production was tested. The optimal level of ammonium sulfate was $2 \%$. Higher concentration of it decreased L-threonine production (Fig. 5).

e) Effect of inorganic salts on L-threonine

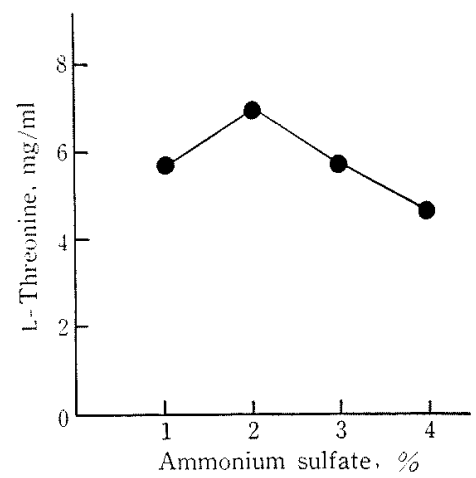

FIG. 5. Effect of Ammonium Sulfate on L-Threonine Production in A, paraffineus KY 7135.

Basal medium; n-paraffin $10 \%, \mathrm{KH}_{2} \mathrm{PO}_{4} 0.1 \%$, $\mathrm{K}_{2} \mathrm{HPO}_{4} 0.1 \%, \mathrm{MgSO}_{4} \cdot 7 \mathrm{H}_{2} \mathrm{O} \quad 0.1 \%$, trace element solution $1 \mathrm{ml} /$ liter, thiamine $1 \mu \mathrm{g} / \mathrm{ml}$, DL-methionine $500 \mu \mathrm{g} / \mathrm{ml}$ (pH 7.4).

Incubation time; 7 days
Table III. Effect of Inorganic Salts on L-Threonine Production in $A$. paraffineus KY7135

Incubation time; 7 days

Basal medium; $n$-paraffin $10 \%,\left(\mathrm{NH}_{4}\right)_{2} \mathrm{SO}_{4} 2 \%$, trace element solution $1 \mathrm{ml} /$ liter, thiamine $1 \mu \mathrm{g} / \mathrm{ml}$, DL-methionine $500 \mu \mathrm{g} / \mathrm{ml}, \mathrm{CaCO}_{3} 2 \%(\mathrm{pH} \mathrm{7.4)}$.

\begin{tabular}{ccc}
\hline $\begin{array}{c}\mathrm{KH}_{2} \mathrm{PO}_{4} \text { and } \\
\mathrm{K}_{0} \mathrm{HPO}_{4}\end{array}$ & $\begin{array}{c}\mathrm{MgSO}_{4} \cdot 7 \mathrm{H}_{2} \mathrm{O} \\
\%\end{array}$ & $\begin{array}{c}\text { L-Threonine } \\
\text { found } \\
\mathrm{mg} / \mathrm{ml}\end{array}$ \\
\hline 0.05 & 0.05 & 7.7 \\
& 0.1 & 8.2 \\
& 0.2 & 7.5 \\
& 0.4 & 6.8 \\
\hline & 0.05 & 9.2 \\
& 0.1 & 10.0 \\
& 0.2 & 7.9 \\
0.2 & 0.4 & 6.7 \\
\hline & 0.05 & 11.5 \\
& 0.1 & 8.6 \\
& 0.2 & 8.3 \\
& 0.4 & 6.1 \\
\hline & 0.05 & 11.4 \\
& 0.1 & 10.0 \\
& 0.2 & 7.9 \\
\hline
\end{tabular}

a) $\mathrm{KH}_{2} \mathrm{PO}_{4}$ and $\mathrm{K}_{2} \mathrm{HPO}_{4}$ were used in $1: 1$ ratio on weight basis. The concentration in the table represents the level of each phosphate.

production. Effect of the concentration of phosphate and magnesium ion on L-threonine production was tested (Table III). Lower concentrations of magnesium sulfate $(0.025 \sim$ $0.05 \%$ were favorable for L-threonine production. The proper ranges of the concentrations of dipotassium hydrogen phosphate and potassium dihydrogen phosphate were $0.2 \sim 0.4 \%$ each. The amount of L-threonine production at the optimal concentrations of the inorganic salts was $11.5 \mathrm{mg} / \mathrm{ml}$.

f) Effect of amino acids, vitamines and precursors on L-threonine production. The effect of 23 natural amino acids including glycine, L-alanine, L-valine, L-leucine, Lisoleucine, $\mathrm{L}$-serine, $\mathrm{L}$-glutamic acid, $\mathrm{L}$-aspartic acid, L-proline, L-ornithine, L-arginine, Ltryptophan, L-tyrosine, L-phenylalanine, Lcystine, L-cysteine, L-homoserine, DL- $a$-aminobutyric acid, L-lysine, L-histidine, L-glutamine, 
Table IV. EfFect of Amino Acids AND Fumaric Acid on L-Threonine Production IN $A$. paraffineus $\mathrm{K} Y 7135$

Incubation time; 7 days

Basal medium; n-paraffin $10 \%,\left(\mathrm{NH}_{4}\right)_{2} \mathrm{SO}_{4} 4 \%$, $\mathrm{KH}_{2} \mathrm{PO}_{4} 0.2 \%, \mathrm{~K}_{2} \mathrm{HPO}_{4} 0.2 \%, \mathrm{MgSO}_{4} \cdot 7 \mathrm{H}_{2} \mathrm{O} 0.05 \%$ trace element solution $1 \mathrm{~m} / /$ liter, thiamine $2 \mu \mathrm{g} / \mathrm{ml}$, DL-methionine $2 \mathrm{mg} / \mathrm{ml}, \mathrm{CaCO}_{3} 2 \%$ (pH 7.4).

\begin{tabular}{lrc}
\hline $\begin{array}{c}\text { Amino acid or } \\
\text { precursor }\end{array}$ & $\mathrm{mg} / \mathrm{ml}$ & $\begin{array}{c}\text { L-Threonine } \\
\text { found } \mathrm{mg} / \mathrm{ml}\end{array}$ \\
\hline \multirow{2}{*}{ Val } & 0.2 & 3.5 \\
& 1.0 & 6.3 \\
& 10.0 & 6.7 \\
& 20.0 & 9.0 \\
\hline \multirow{3}{*}{ Leu } & 0.2 & 5.4 \\
& 1.0 & 4.2 \\
& 10.0 & 5.9 \\
Asp & 20.0 & 6.2 \\
\hline \multirow{3}{*}{ Glu } & 0.2 & 5.6 \\
& 1.0 & 4.2 \\
& 10.0 & 7.5 \\
& 20.0 & 8.1 \\
\hline Fumaric acid & 0.2 & 3.8 \\
& 1.0 & 3.3 \\
\hline Homoserine & 10.0 & 7.2 \\
& 20.0 & 7.5 \\
\hline
\end{tabular}

L-asparagine and $a, \varepsilon$-diaminopimelic acid on L-threonine production was investigated. A part of the results is presented in Table IV. Addition of L-valine or L-aspartic acid at high level $(1 \sim 2 \%)$ enhanced L-threonine production to some extent. High concentration of L-leucine stimulated the growth, whereas its effect on L-threonine production was slight. Addition of L-homoserine, a threonine precursor, gave no prominant effect on L-threonine production, whereas addition of it at high level reduced the bacterial growth.

Addition of fumaric acid stimulated Lthreonine production to some extent (Table IV).

With addition of riboflavine, or biotin,
TAble V. EFfect of Vitamines on L-Threonine Production IN $A$. paraffineus KX7135

The medium described in the legend of Table IV was used for the basal medium.

Incubation time; 7 days

\begin{tabular}{lcc}
\hline Vitamines & $\mu \mathrm{g} / \mathrm{ml}$ & $\begin{array}{c}\text { L-Threonine found } \\
\mathrm{mg} / \mathrm{ml}\end{array}$ \\
\hline Riboflavine & 0.4 & 0.3 \\
& 4.0 & 2.7 \\
\hline Biotin & 0.4 & 4.7 \\
& 4.0 & 0.6 \\
\hline Control & - & 6.0 \\
\hline
\end{tabular}

Table VI. Effect of Natural Nutrients on L-Threonine Production in A. paraffinelts KY7135

The medium described in the legend of Table IV was used for the basal medium.

Incubation time: 7 days

\begin{tabular}{llc}
$\begin{array}{c}\text { Natural } \\
\text { nutrients }\end{array}$ & \multicolumn{1}{c}{$\%$} & $\begin{array}{c}\text { L-Threonine found } \\
\mathrm{mg} / \mathrm{ml}\end{array}$ \\
\hline \multirow{3}{*}{ Yeast extract } & 0.05 & 8.3 \\
& 0.1 & 9.6 \\
& 0.25 & 9.3 \\
& 0.5 & 7.9 \\
\hline \multirow{3}{*}{ Peptone } & 0.05 & 5.4 \\
& 0.1 & 8.8 \\
& 0.25 & 7.6 \\
Corn steep liquor & 0.5 & 5.9 \\
\hline \multirow{3}{*}{ Meat extract } & 0.05 & 7.7 \\
& 0.1 & 6.2 \\
& 0.25 & 6.6 \\
& 0.5 & 4.8 \\
\hline Control & 0.05 & 7.3 \\
& 0.1 & 7.3 \\
& 0.25 & 8.1 \\
\hline & 0.5 & 6.5 \\
\hline
\end{tabular}

both L-threonine production and the growth were repressed (Table V). The other vitamines including $p$-aminobenzoic acid, pyridoxine, pantothenic acid, folic acid, cyanocobalamine, inositol and nicotimic acid $(0.4$ and $4 \mu \mathrm{g} /$ ml) showed slight effect at best.

g) Effect of various natural nutrients on L-threonine production. Yeast extract, peptone, meat extract and corn steep liquor were tested for their effect on L-threonine 
production. As shown in Table VI, all of them showed stimulatory effects on L-threonine production. Yeast extract was proved to be the most favorable nutrient for L-threonine production.

h) Effect of various sugars, organic acid and alcohols on L-threonine production. The effect of various sugars, organic acids and alcohols on $\mathrm{L}$-threonine production was studied in attempts not only to increase L-threonine production but also to shorten the fermentation time. Results with the compounds effective on $L$-threonine production are summerized in Tables VII and VIII. Among monocarboxylic acids, including myristic, lauric, capric, pelargonic, enanthic, caprylic, caproic, palmitic, stearic and linoleic acids, myristic acid $\left(\mathrm{C}_{14}\right)$, n-capric acid $\left(\mathrm{C}_{10}\right)$, pelargonic acid $\left(\mathrm{C}_{9}\right)$ and enanthic acid $\left(\mathrm{C}_{7}\right)$ showed stimulatory effect on L-threonine production (Table VII). As for dicarboxylic acids including succinic, glutaric, adipic, pimelic, suberic, azeraic and sebacic acids addition of sebacic acid or glutaric acid at low level $(60 \sim 125 \mu \mathrm{g} / \mathrm{ml})$ enhanced

TABle VII. EFFect of Organic Acids on L-Threonine Production IN $A$. paraffineus KY7135

Incubation time; 7 days

Basal medium; $n$-paraffine $10 \%,\left(\mathrm{NH}_{4}\right)_{2} \mathrm{SO}_{4} 2 \%$, $\mathrm{KH}_{2} \mathrm{PO}_{4} 0.2 \%, \mathrm{~K}_{2} \mathrm{HPO}_{4} 0.2 \%, \mathrm{MgSO}_{4} \cdot 7 \mathrm{H}_{2} \mathrm{O} 0.05 \%$, trace element solution $1 \mathrm{ml} /$ liter, thiamine $2 \mu \mathrm{g} / \mathrm{ml}$, DL-methionine $2 \mathrm{mg} / \mathrm{ml}, \mathrm{CaCO}_{3} 2 \%$ (pH 7.4).

\begin{tabular}{rcc}
\hline Organic acids & $\%$ & $\begin{array}{c}\text { L-Threonine } \\
\text { found } \mathrm{mg} / \mathrm{ml}\end{array}$ \\
\hline Myristic & 0.006 & 10.4 \\
acid & 0.012 & 10.0 \\
\hline$n$-Capric & 0.006 & 10.6 \\
acid & 0.012 & 9.4 \\
\hline Pelargonic & 0.006 & 11.5 \\
acid & 0.012 & 6.9 \\
\hline Enanthic & 0.006 & 10.4 \\
acid & 0.012 & 8.3 \\
\hline$n$-Caproic & 0.006 & 6.9 \\
acid & 0.012 & 4.3 \\
\hline Palmitic & 0.006 & 4.8 \\
acid & 0.012 & 7.9 \\
\hline Control & - & 9.2 \\
\hline
\end{tabular}

Table VIII. EFFect of Dicarboxylic Acids on L-Threonine Production In A. paraffineus KY7135

The medium described in the legend of Table VII was used for the basal medium.

Incubation time; 7 days

\begin{tabular}{llc}
\hline $\begin{array}{c}\text { Dicarboxylic } \\
\text { acids }\end{array}$ & $\%$ & $\begin{array}{c}\text { L-Threonine } \\
\text { found } \mathrm{mg} / \mathrm{ml}\end{array}$ \\
\hline Succinic acid & 0.006 & 6.0 \\
& 0.012 & 8.4 \\
\hline Glutaric acid & 0.006 & 8.6 \\
& 0.012 & 9.1 \\
\hline Suberic acid & 0.006 & 5.5 \\
& 0.012 & 5.4 \\
\hline Sebacic acid & 0.006 & 9.8 \\
& 0.013 & 7.6 \\
& 0.025 & 6.2 \\
\hline Azeraic acid & 0.05 & 6.0 \\
\hline Control & 0.006 & 5.3 \\
\hline
\end{tabular}

Table IX. L-Threonine Production BY MONOCOLONY ISOLATES OBTAINED FROM A. paraffineus KY7135

The medium described in the legend of Table VII was used.

Incubation time; 7 days

\begin{tabular}{lcc}
\hline Isolate No. & $\begin{array}{c}\text { L-Threonine } \\
\text { found } \mathrm{mg} / \mathrm{ml}\end{array}$ & $\begin{array}{c}\text { L-Valine } \\
\text { found }\end{array}$ \\
\hline $42-7 \mathrm{~B}-7$ & 14.5 & $\pm \sim+$ \\
$42-7 \mathrm{~B}-13$ & 14.0 & $\pm \sim+$ \\
$42-7 \mathrm{~B}-19$ & 12.6 & $\pm \sim \pm$ \\
$42-7 \mathrm{C}-2$ & 12.5 & $\pm \sim+$ \\
$42-7 \mathrm{C}-8$ & 13.0 & trace \\
KY7135 & 9.8 & $\pm \sim+$ \\
\hline
\end{tabular}

L-threonine production (Table VIII). Addition of sugars (glucose, mannitol, sorbitol, or fructose at 1 or $2 \%$ ) was found to decrease L-threonine production.

An attempt to shorten the fermentation time has not been successful so far.

i) Monocolony isolates from KY7135. Fifty isolates were obtained from KY7135 by monocolony procedure. Among them, five isolates produced above $12 \mathrm{mg} / \mathrm{ml}$ of L-threonine with the medium containing $10 \% n$ - 
paraffin and $2000 \mu \mathrm{g} / \mathrm{ml}$ of DL-methionine (Table IX).

\section{DISCUSSION}

An isoleucine leaky auxotroph of Arthrobacter paraffineus, which produced a large amount of both L-threonine and L-valine from $n$-paraffin at the same time, was mutagenized to obtain better L-threonine producers. In a previous paper, ${ }^{1)}$ it was found that some double auxotrophs increased L-threonine productivity as compared with the parent single auxotroph and some isoleucine revertants of triple-less auxotrophs of Escherichia coli produced more L-threonine than the parent strains. In view of these findings, many double auxotrophs and its revertants with respect to isoleucine requirement were derived from the mutant of $A$. paraffineus. It has now been found that some of the double auxotrophs and the revertants increased in threonine productivity also in $A$. paraffineus. Threonine producing mutants described here may be regulatory mutants as discussed by Takayama et al $^{3}$ although evidence supporting this speculation awaits to be obtained. Double auxotrophs might be able to release from the control by corresponding end products and favorable for $\mathrm{L}$-threonine production. The cause of the increase of $\mathrm{L}$-threonine production in the revertants has not been clarified so far.

The amount of L-valine produced in some isoleucine revertants was largely decreased.
Takayama et $a l^{37}$ reported that excessive addition of L-isoleucine in the medium inhibited the production of L-Valine in the isoleucine auxotroph of $A$. paraffineus. Hence, it is assumed that the decrease of L-valine production in isoleucine revertants may be due to the supression of L-valine biosynthesis by $\mathrm{L}$-isoleucine readily synthesized in the revertants.

With carbohydrate medium such as mannitol or sorbitol, higher levels of L-methionine (above $100 \mu \mathrm{g} / \mathrm{ml}$ ) supressed L-threonine production, whereas with $n$-paraffin medium high levels $(1000 \sim 2000 \mu \mathrm{g} / \mathrm{ml})$ of it were favorable for L-threonine production (Table I). Similar phenomena were also reported in L-ornithine, ${ }^{4}$, L-citrulline $^{5)}$ or L-homoserine ${ }^{6)}$ production in hydrocarbon utilizer. Presumably, the difference in the level of requirement between carbohydrate medium and $n$-paraffin medium was due to the difference in the uptake rate of the requiring amino acids.

\section{REFERENCES}

1) H. Kase, H. Tanaka and K. Nakayama, Agr. Biol. Chem., 35, 2089 (1971).

2) H. Kase and K. Nakayama, ibid., 36, 1611 (1972).

3) K. Takayama, S. Abe and S. Kinoshita, Amino Acid and Nucleic Acid, No. 19, 121 (1969).

4) K. Tanaka, K. Oshima, Y. Tokoro and S. Kinoshita, ibid., No. 18, 57 (1968).

5) Y. Tokoro, K. Oshima, K. Tanaka and S. Kinoshita, ibid., No. 19, 115 (1969).

6) K. Oshima, Y. Tokoro, S. Okii, K. Tanaka and S. Kinoshita, ibid., No. 20, 1 (1969). 